\title{
Social and Economic Vulnerability in The Sub-Watershed of Karang Mumus, East Kalimantan Province
}

\author{
Sri Endayani ${ }^{1}$, Ronggo Sadono ${ }^{{ }^{*}}$, Ambar Kusumandari ${ }^{1}$, Hartono $^{2}$ \\ ${ }^{1}$ Department of Forest Management, Faculty of Forestry, Universitas Gadjah Mada, Jl. Agro No 1, Bulaksumur, \\ Yogyakarta, Indonesia 55281 \\ ${ }^{2}$ Department of Geography, Faculty of Geography, Universitas Gadjah Mada, Sekip Utara, Jl. Kaliurang, Yogyakarta, \\ Indonesia 55281
}

Received April 16, 2019/Accepted July 24, 2019

\begin{abstract}
Changes in land use influence the social and economic characteristics as well as the environmental problems in a sub-watershed. To support the management of a sub-watershed, land use scenarios (biophysics) must be prepared and community involvement level must be improved. So far, the factors used for monitoring and evaluating subwatershed performance have not been used thoroughly. This research is aimed at finding out the social and economic vulnerabilities tied to the monitoring and evaluation of sub-watershed performance across the sub-districts. This research uses quantitative methods employed to process primary data (biotic: vegetation and settlement, and abiotic: land, climate, geomorphology, and geology), secondary data (community data sourced from the data of BPS; Central Bureau of Statistics) of East Kalimantan Province; in September 2017), and socio-economic data (direct interviews using questionnaires). The primary data were obtained after processing map interpretation and from observation. The results show that high socio-economic vulnerability occurs in areas of high land use vulnerability. Sub-watershed management will be successful if it is done through a "collaborative management" involving all stakeholders. The scenario simulations of this research can be used as reference materials for regional governments in planning, compiling, and implementing the Regional Spatial Plan policies.
\end{abstract}

Keywords: performance monitoring and evaluation, collaborative management, community participation, land use scenario (biophysics)

*Correspondence author, email: rsadono@ugm.ac.id, tel.: +62-274-548815,fax: +62 -274-548815

\section{Introduction}

Karang Mumus Sub-Watershed is one of the critical subwatersheds in Samarinda (BPS, 2017), which includes several sub-districts such as Samarinda Kota, Samarinda Ilir, Sambutan, Sungai Pinang, and Samarinda Utara. This critical condition is caused by the increasing number of agricultural practices disregarding conservation rules and thus resulting in a very high ratio of the maximum and minimum discharge of the river and sedimentation that exceeds the threshold of erosion (Bawole, 2013). A sub-watershed is greatly affected by the upstream conditions, particularly the biophysical conditions of the water absorption and catchment areas (Turner et al., 1995).

Many places in the upstream area are prone to human disturbance. This implies that sub-watershed sustainability is conditional on behavior patterns, socio-economic circumstances, and the management level which is very closely related to institutional arrangement (Gunawan, 2008). According to Gunawan (2008), human activities are a major cause of sub-watershed damages leading to the advent of natural disasters, such as floods and landslides. In addition, the shape of a sub-watershed contributes greatly to the occurrence of flood. An example of the cases occurring in Karang Mumus Sub-Watershed that has become a national issue is the damages in the upstream region, especially in the District of Samarinda Utara. Samarinda Utara Sub-District suffers from severe damages due to land degradation and an annual erosion of around 161 ton $\mathrm{ha}^{-1}$, both of which have caused sedimentation in Benanga Reservoir (Hydro Power Center) many fear would cause an energy crisis (www.KaltimPOS.com). Meanwhile, Samarinda Utara, Samarinda Ilir, and Sambutan suffer from river pollution and streambank erosion resulting from coal mining (www.tribunnews.com).

In light of these environmental damages, the subwatershed performance monitoring and evaluation (monev) is necessary (Innah, 2013). Sub-watershed performance monev itself includes simple, practical, scalable, and easily understood data and facts observation and analysis performed against the sub-watershed performance criteria and indicators for land, social, economic, and institutional 
management so as to determine the "status" or "health level" of a sub-watershed (P.04/VSET/2009, 2009). So far, the subwatershed performance monev only consider certain aspects, which are either socio-economic aspects or biophysical aspects only (Karminarsih, 2007). As an illustration, the management of Karang Mumus Sub-Watershed is still partial, sectoral, or limited by administrative authority (Rusdiana, 2013).

Sub-watershed performance monev can be done by examining the interconnectedness between the vulnerability of socio-economic and biophysical aspects (Kartodihardjo, 2013). The vulnerability identification of both socioeconomic and biophysical aspects in the sub-watershed is still partial and unintegrated (Suarga, 2005). Socio-economic vulnerability is closely related to the natural resources in a particular area. Areas with degraded land will create socioeconomic vulnerability if the only main source of income is from the agricultural sector (Mulyanto, 2004). Flood vulnerability is only closely examined in the flooded areas. None has ever performed a comprehensive analysis that includes the upstream region (Nugroho, 2011). It is expected that the results of this study can be used to identify the interconnectedness between the socio-economic and biophysical vulnerability of the sub-watershed (Siahaan, 2008).

\section{Methods}

Theory Purwanto (2015) argues that the factors causing environmental degradation in the forest can be grouped into two, namely abiotic and biotic factors. Abiotic factors include soil, climate, water, geology, and geomorphology. Meanwhile, biotic factors include settlement, vegetation, and population (Soedomo, 2013). A geomorphologically vulnerable region is prone to erosion, floods, landslides, and drought (Sulistiyono, 2015). Climate/high rainfall can potentially cause damages to the land (Sembiring, 2010). Human land/forest use activities exceeding the carrying capacity of the environment and or disregarding the rules of soil and water conservation are caused by the lack of knowledge, skills, and attitude/moral (Zulkarnaen, 2008). Therefore, for the natural resources in the form of forest, land, and water to be sustainably beneficial for the welfare of mankind, the management principles of protected forests should be implemented comprehensively and integrated in accordance with the biophysical characteristics of land for the sake of forest and land rehabilitation (Timpakul, 2007).

Sub-watershed management is an effort to manage the reciprocal relationship between natural resources, especially vegetation, soil and water, and human resources within the sub-watershed, and all of their activities to gain economic benefits and environmental services for the development and ecosystem sustainability of the sub-watershed itself (Susilo, 2009). Sub-watershed management is in accordance with both the socio-economic and biophysical of each subwatershed. Therefore, sub-watershed management must be done in an integrated and comprehensive manner (Walker, 2006).

Research sites Karang Mumus Sub-watershed is one of the sub-watersheds currently suffering from very heavy damages (Figure 1). Due to deforestation and land degradation caused by oil palm plantations and communitymanaged coal mines (the northern part of Samarinda Kota), the central and downstream sections of the sub-watershed are suffering from river pollution. This results in a decline in the quality of river water used to meet the needs of the community in Samarinda Kota, Samarinda Ilir, Sungai Pinang, Sambutan, and Samarinda Utara Sub-Districts (Amin, 2009). The proportion of each sub-district included in Karang Mumus Sub-Watershed can be seen in Table 1.

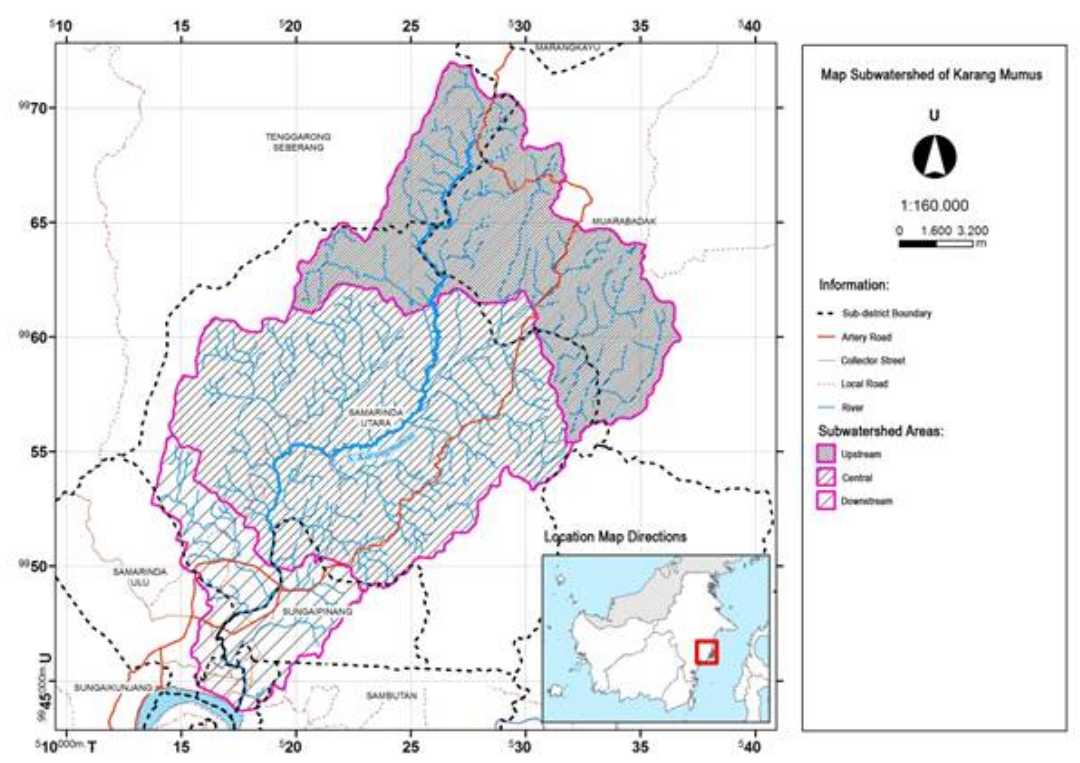

Figure 1 Map of Karang Mumus Sub-Watershed. 
Table 1 The total area of Karang Mumus Sub-Watershed (Samarinda Utara, Sambutan, Sungai Pinang, Samarinda Ilir, and Samarinda Kota)

\begin{tabular}{|c|c|c|c|c|c|c|c|}
\hline \multirow[b]{2}{*}{$\begin{array}{l}\text { Part } \\
\text { sub-watershed }\end{array}$} & \multicolumn{5}{|c|}{ Sub district (ha) } & \multirow{2}{*}{ Total (ha) } & \multirow{2}{*}{ Percentage } \\
\hline & $\begin{array}{c}\text { Samarinda } \\
\text { Utara }\end{array}$ & Sambutan & $\begin{array}{l}\text { Sungai } \\
\text { Pinang }\end{array}$ & $\begin{array}{l}\text { Samarinda } \\
\text { Ilir }\end{array}$ & $\begin{array}{l}\text { Samarinda } \\
\text { Kota }\end{array}$ & & \\
\hline Upstream & $1,150.89$ & & & & $4,509.21$ & $5,660.10$ & 18 \\
\hline Central & $8,087.65$ & $1,484.20$ & & $6,779.54$ & & $16,351.39$ & 52 \\
\hline Downstream & & $7,983.88$ & $1,449.61$ & & & $9,433.50$ & 30 \\
\hline Total (ha) & $9,238.54$ & $9,468.09$ & $1,449.61$ & $6,779.54$ & $4,509.21$ & $31,444.99$ & \\
\hline Proportion (\%) & 29.38 & 30.11 & 4.61 & 21.56 & 14.34 & & \\
\hline
\end{tabular}

Materials and equipment The materials and equipment used in this study are questionnaires, notes, office stationery, documentation equipment, recorders, cameras, RBI map Indonesia, Digital Elevation Model (DEM) map, soil map, and land use map.

This research employs the quantitative method. The vulnerability in Karang Mumus Sub-Watershed is categorized into biophysical and socio-economic vulnerabilities using the sub-watershed Level Characteristics System Formulation (Paimin, 2002). The data obtained is analyzed using the Arc GIS 10.1 software. The vulnerability itself can be classified further into 5 scales: scale 5 (very vulnerable), scale 4 (vulnerable), scale 3 (medium), scale 2 (somewhat vulnerable), and scale 1 (not vulnerable). Stages of research are conducted to find:

(1) People's vulnerability to land. The parameters sought are population density and economic structure. Measurement results are shown in Table 2.

(2) Sub-watershed economic vulnerability. The parameters sought are income and economic growth. Economic vulnerability measurement results are shown in Table 3.

(3) Vulnerability/sensitivity of sub-watershed management area. The parameters sought are the area of the subwatershed and the administrative area. The results are shown in Table 4.

(4) Lands' vulnerability to erosion. The parameters sought are landform/system and land cover. Measurement results are shown in Table 5.

(5) The interconnectedness between socio-economic and biophysical aspects (land typology) are set out in the catchment typology (rainwater catchment area) (Paimin, 2009). Table 6 shows that higher category value means worse corresponding parameter, and vice versa.

(6) Once the conditions pertaining to Karang Mumus SubWatershed were known, an analysis to determine the interconnectedness of socio-economic and biophysical aspects in relation to sub-watershed performance was performed using the quantitative-descriptive method.

Socio-economic data were collected using questionnaireguided interviews and in-depth interviews with key figures (key persons) for data validation. Respondents were randomly selected and proportionately adjusted to the purpose of the research (Wijaya, 2015). Biophysical data
Table 2 The scale of people's vulnerability to land

\begin{tabular}{lccc}
\hline Population density & \multicolumn{3}{c}{ Economic structure } \\
\cline { 2 - 4 }$\left(\right.$ People $\left.\mathrm{km}^{-2}\right)$ & Agriculture & Industry & Service \\
\hline Low (<250) (1) & 3 & 2 & 1 \\
Medium (250-400) (2) & 4 & 3 & 2 \\
High (>400) & 5 & 4 & 3
\end{tabular}

Source: Paimin (2009)

Description (details): The number in the brackets () indicates the score of each parameter

were collected using a survey based on satellite imageries, Google Earth images and Indonesia RBI map to identify the actual land cover. Data such as sub-watershed boundaries, slope, and morphometry were obtained from the digital elevation model (DEM) map. The identification of erosion, landslides, floods, and land cover was performed through field checks (Wiyono, 2008). The collection of secondary data was conducted in relevant agencies, namely the SubWatershed Management Center (BPDAS), Office of Public Works (PU), Office of Agriculture, Department of Forestry, Office of National and Political unity (Kesbangpol), and Central Bureau of Statistics (BPS). The thought flow used to determine sub-watershed typology can be seen in Figure 2.

The data obtained were analyzed using the quantitativedescriptive approach to determine the interconnectedness between the socio-economic and biophysical aspects of subwatershed performance. The interconnectedness was measured based on the vulnerability scale of each socioeconomic and biophysical typology, in which higher scale means worse sub-watershed condition. This was done using the Arc GIS 10.1 software. To learn the source causes of vulnerability, high value parameters were examined so that recommendations can be tailored to the severity of the problems at hand.

\section{Results and Discussion}

Socio-economic vulnerability (people's vulnerability to 
Table 3 Sub-watershed economic vulnerability scale

\begin{tabular}{lccccc}
\hline \multirow{2}{*}{ Income } & \multicolumn{5}{c}{ Economic growth } \\
\cline { 2 - 6 } & $\begin{array}{c}\text { Samarinda Utara } \\
\text { Sub-District }\end{array}$ & $\begin{array}{c}\text { Sambutan Sub- } \\
\text { District }\end{array}$ & $\begin{array}{c}\text { Sungai Pinang Sub- } \\
\text { District }\end{array}$ & $\begin{array}{c}\text { Samarinda Ilir Sub- } \\
\text { District }\end{array}$ & $\begin{array}{c}\text { Samarinda Kota } \\
\text { Sub-District }\end{array}$ \\
\hline$>1.5$ SK (1) & 1 & 1.5 & 2 & 2.5 & 3 \\
$1.26-1.5$ SK (2) & 1.5 & 2 & 2.5 & 3 & 3.5 \\
$1.1-1.25$ SK (3) & 2 & 2.5 & 3 & 3.5 & 4 \\
$0.67-1$ SK (4) & 2.5 & 3 & 3.5 & 4 & 4.5 \\
$<0.67$ SK (5) & 3 & 3.5 & 4 & 4.5 & 5 \\
\hline
\end{tabular}

SK $($ standar kemiskinan $)=$ poverty standards. The number in the brackets () indicates the score of each parameter

Table 4 Sub-watershed management territorial vulnerability/sensitivity

\begin{tabular}{lccc}
\hline & \multicolumn{3}{c}{ Administrative territory } \\
\cline { 2 - 4 } Sub-watersheds' area (ha) & $\begin{array}{c}\text { Within the } \\
\text { sub-district }\end{array}$ & $\begin{array}{c}\text { Across sub- } \\
\text { districts/within } \\
\text { the sub-district }\end{array}$ & $\begin{array}{c}\text { Across sub- } \\
\text { districts }\end{array}$ \\
\hline Small (<0.15 million) & 1 & 2 & 3 \\
Medium (0.15-0.5 million) & 2 & 3 & 4 \\
Big (>0.5 million) & 3 & 4 & 5 \\
\hline
\end{tabular}

Source: Paimin (2009)

Table 5 Land vulnerability/sensitivity to erosion scale

\begin{tabular}{|c|c|c|c|c|c|c|}
\hline \multirow[b]{2}{*}{ Land form/land system } & \multicolumn{6}{|c|}{ Closure of land } \\
\hline & Building & $\begin{array}{c}\text { Protection and } \\
\text { conservation } \\
\text { forest }\end{array}$ & $\begin{array}{l}\text { Production } \\
\text { forest/ } \\
\text { plantation }\end{array}$ & $\begin{array}{c}\text { Fields, grass, } \\
\text { and } \\
\text { shrubs/thicket }\end{array}$ & Settlement & $\begin{array}{c}\text { Moor and } \\
\text { lithosols }\end{array}$ \\
\hline Marshes & 1 & 1 & 1 & 1 & 1 & 1 \\
\hline Alluvial plains and alluvial valleys & 1 & 1.5 & 1.5 & 2 & 2 & 2.5 \\
\hline Plain & 1 & 2 & 2.5 & 3 & 3.5 & 4 \\
\hline Mountains and hills & 1 & 3 & 3.5 & 4 & 4.5 & 5 \\
\hline
\end{tabular}

Details: the number in the brackets () indicates the score of each parameter; source: Paimin (2009)

Table 6 Sub-watershed level vulnerability classification

\begin{tabular}{lcc}
\hline \multicolumn{1}{c}{ Category } & Value & Vulnerability/degradation level \\
\hline Very high & $>4.3$ & Very vulnerable \\
High & $>3.5-4.3$ & Vulnerable \\
Moderate & $>2.6-3.4$ & Medium \\
Low & $>1.7-2.5$ & Somewhat vulnerable \\
Very low & $<1.7$ & Not vulnerable
\end{tabular}

Source: Paimin (2009) 


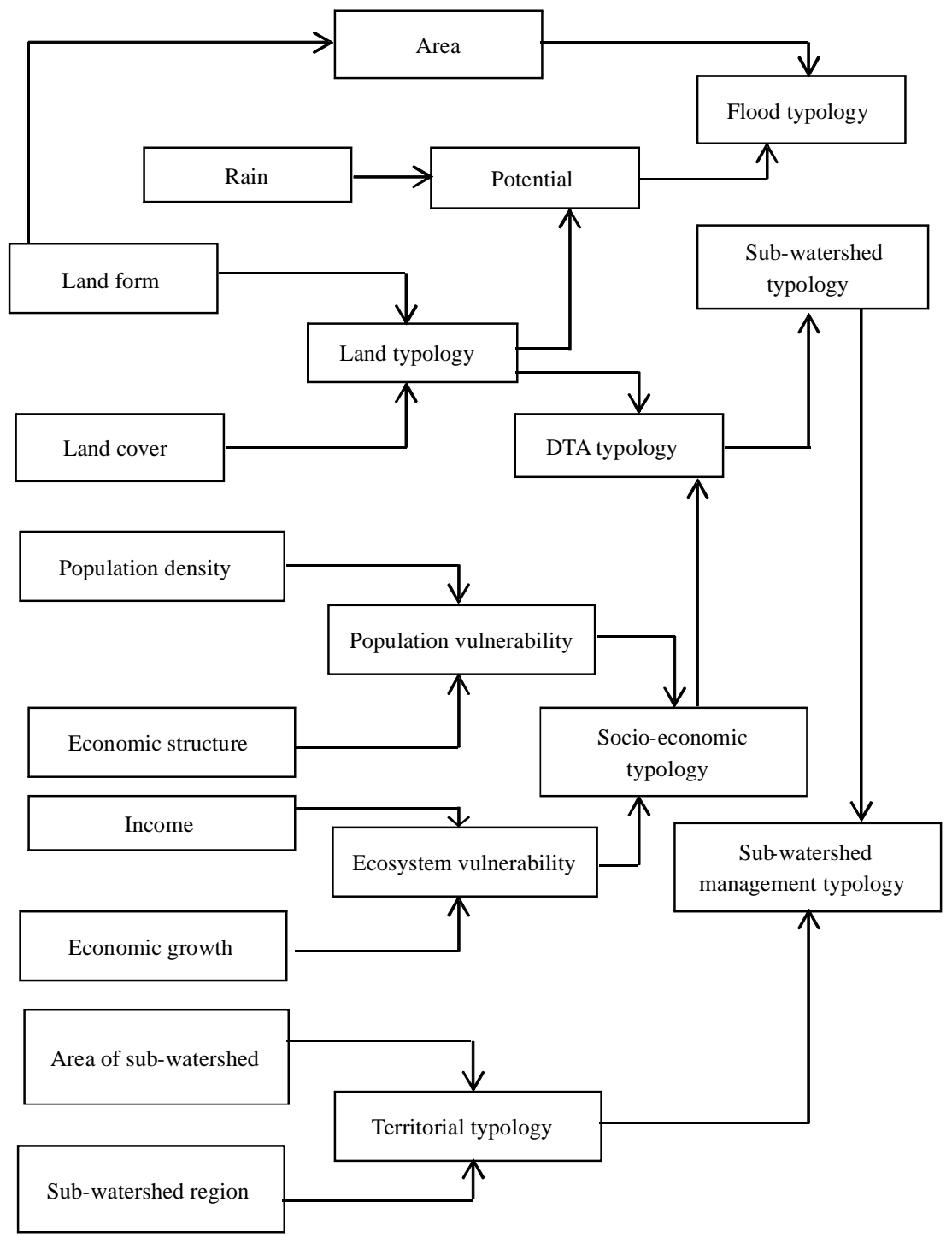

Figure 2 Sub-watershed typology analysis thought flow (Paimin, 2012).

land) A sub-watersheds' socio-economic conditions affect the sustainability of its natural resources. Table 7 shows five districts, namely Samarinda Kota, Samarinda Ilir, Sungai Pinang, Sambutan, and Samarinda Utara, that have a population density of more than 400 people $\mathrm{km}^{-2}$ and have an agriculture-based economic structure. Population density and agriculture-based economic structure are indicators suggesting vulnerability. Thus, these sub-districts can be categorized as highly vulnerable, especially Samarinda Kota which has industrial economic but has a population density of more than 400 people $\mathrm{km}^{-2}$. In general, people's vulnerability to land in Karang Mumus Sub-Watershed is categorized as very vulnerable.

Economic vulnerability Karang Mumus Sub-Watersheds' economic vulnerability can be observed from its income and economic growth. High vulnerability is observed in the Sub-
District of Samarinda Kota, with its income still falls below the threshold of its own standard poverty (IDR201,651.00 capita $^{-1}$ month $^{-1}$ ) that is equal to 0.95 (BPS, 2017). Meanwhile, Samarinda Ilir, Sungai Pinang, and Sambutans' vulnerability is categorized as medium because their per capita income is still above the poverty threshold. The most vulnerable subdistrict is Samarinda Utara and therefore it becomes a priority in the implementation of management and development. In general, Karang Mumus Sub-Watershed economic vulnerability can be seen in Table 8 .

Karang Mumus Sub-Watersheds' income and economic growth typology is categorized as vulnerable. The parameter contributing the most to this vulnerability is the people's vulnerability to land (high population density and agriculture-based economic structure). In Sungai Siring Village (a village in the upstream region), land with steep slopes are still used to farm. As a result, the soil layer is 
getting thinner. More and more rocks start to be exposed, forcing farmers to use more and more fertilizer when farming. In light of the influence of people's vulnerability to land on the typology of income and economic growth, Karang Mumus Sub-Watersheds' vulnerability can be seen in Table 9.

\section{Biophysical vulnerability}

Division of Karang Mumus Sub-Watershed Karang Mumus Sub-Watershed is further divided into (1) Karang Mumus Hulu Sub-Watershed that includes Siring, Tanah Merah, and Lempake Sub-Watershed, (2) Karang Mumus Tengah 1 Sub-Watershed that includes Sungai Pinang and Gunung Lingai Sub-Watersheds, (3) Karang Mumus Tengah 2 Sub-Watershed that includes Gunung Kelua and the Sidodadi Sub-Watersheds, and (4) Karang Mumus Hilir SubWatershed that includes Sungai Pinang Luar, Sidomulyo, and the Sungai Dama Sub-Sub-Watersheds.

Land typology Land typology is characterized by land system and land cover. A land systems is established based on ecological principles by assuming that there is a close relationship between rock types, hydroclimate, landform, soil, and organisms. A land system consists of a combination of parent rock, soil, and topography with similar potentials and limiting factors (Turner et al., 1995). Based on the land system, Karang Mumus Sub-Watershed is divided into 18 land systems, namely: Sungai Siring, Tanah Merah, Lempake, Gunung Lingai, Sempaja Utara, Sempaja Selatan, Gunung Kelua, Temindung Permai, Sidodadi, Dadimulya, Bandara, Pelita, Sungai Pinang Luar, Sidomulyo, Sidodamai, Karang Mumus, Sungai Dama, and Selili. A land systems' characteristics specifically include land form condition, lithology, soil, and climate. Karang Mumus SubWatershed land cover data are obtained from the 1:50,000 scaled RBI map. The land cover in Karang Mumus SubWatersheds' is categorized into water bodies (fresh water and salt water), marshes, bushes/shrubs, settlements, rice fields (irrigation and rainfed), plantations, forests, and moorlands.

Table 7 People's vulnerability to land

\begin{tabular}{lrlc}
\hline \multicolumn{1}{c}{ Sub-district } & $\begin{array}{c}\text { Population } \\
\text { density (people } \\
\left.\mathrm{km}^{-2}\right)\end{array}$ & $\begin{array}{c}\text { Economic } \\
\text { structure }\end{array}$ & $\begin{array}{c}\text { Vulnerability } \\
\text { (scale 1-5) }\end{array}$ \\
\hline Samarinda Utara & 791.50 & Agriculture & 5 \\
Sambutan & 805.32 & Agriculture & 5 \\
Sungai Pinang & $1,115.40$ & Agriculture & 5 \\
Samarinda Ilir & 742.82 & Industry & 4 \\
Samarinda Kota & 119.04 & Industry & 4 \\
\hline Total & $4,574.08$ & & \\
\hline Average & 914.82 & & \\
\hline
\end{tabular}

Source: BPS (2017)
The distribution of land system in Karang Mumus SubWatershed is shown in Figure 3, while the distribution of land cover can be seen in Figure 4. The results of the interaction between land form/system and land cover can be seen in Figure 5.

In Lempake Jaya, $58 \%$ of the land is categorized as vulnerable, and $22 \%$ are categorized as very vulnerable. In Sempaja, $64 \%$ of the land is categorized as vulnerable, and $31 \%$ (Samarinda Utara Sub-District) is categorized as very vulnerable. In Benanga Village, $56 \%$ of the land is vulnerable, and the remaining $34 \%$ is very vulnerable. In Gunung Kapur, $51 \%$ of the land is deemed vulnerable, while $20 \%$ of the land is very vulnerable (Sungai Pinang SubDistrict). In light of this condition, the four villages should receive priority treatment.

Flood typology Flood typology is divided into two, namely the potential flood water supply and flooded areas (flood recipients). In general, the daily maximum rainfall in Karang Mumus Sub-Watershed ranges from $60 \mathrm{~mm}^{-1}$ day $^{-1}$ (average) up to $280 \mathrm{~mm} \mathrm{day}^{-1}$ (very high). Thus, the potential flood water supply in Karang Mumus Sub-Watershed ranges from moderate to very high.

The sub-watersheds with high flood supply vulnerability $(87 \%)$ are located in Sungai Pinang and Samarinda Kota Sub-Districts. These Sub-Watersheds are Pampang, Karang Mumus Hulu, and Tulis Sub-Watersheds, all of which belong to the upstream region of Karang Mumus Sub-Watershed. These three sub-watersheds are categorized as very vulnerable. Similar condition also occurs in the Samarinda Kota Region of Karang Mumus Hilir Sub-Watershed. The central part of Karang Mumus Sub-Watershed is $38-57 \%$ vulnerable to flood water supply. Considering that flood water supply vulnerability is determined by the maximum daily rainfall (natural conditions), the effects of flood in the downstream region area which is very vulnerable to flood water supply must be dealt with by performing adequate water conservation efforts, both through vegetative measure and civil engineering. The flood-prone areas in Karang

Table 8 Economic vulnerability

\begin{tabular}{lccc}
\hline \multicolumn{1}{c}{ Districts } & Income & $\begin{array}{c}\text { Economic } \\
\text { growth (\%) }\end{array}$ & $\begin{array}{c}\text { Vulnerability } \\
\text { scale (1-5) }\end{array}$ \\
\hline Samarinda Utara & 0.95 & 4.02 & 4 \\
Sambutan & 1.23 & 5.11 & 3 \\
Sungai Pinang & 1.09 & 5.61 & 3 \\
Samarinda Ilir & 5.39 & 1.53 & 3 \\
Samarinda Kota & 1.17 & 5.49 & 3 \\
\hline Total & 9.83 & 21.76 & 16 \\
\hline Average & 7.97 & 4.35 & 3.2 \\
\hline
\end{tabular}

Source: BPS (2017) 
Table 9 Karang Mumus Sub-Watersheds' socio-economic typology

\begin{tabular}{lccc}
\hline \multicolumn{1}{c}{ Districts } & $\begin{array}{c}\text { People's } \\
\text { vulnerability to } \\
\text { land }\end{array}$ & $\begin{array}{c}\text { Economic } \\
\text { vulnerability }\end{array}$ & $\begin{array}{c}\text { Socio- } \\
\text { economic } \\
\text { typology }\end{array}$ \\
\hline Samarinda Utara & 5 & 4 & 4.5 \\
Sambutan & 5 & 3 & 4 \\
Sungai Pinang & 5 & 3 & 4 \\
Samarinda Ilir & 4 & 3 & 3.5 \\
Samarinda Kota & 5 & 3 & 4 \\
\hline Average & 4.8 & 3.2 & 4.0 \\
\end{tabular}
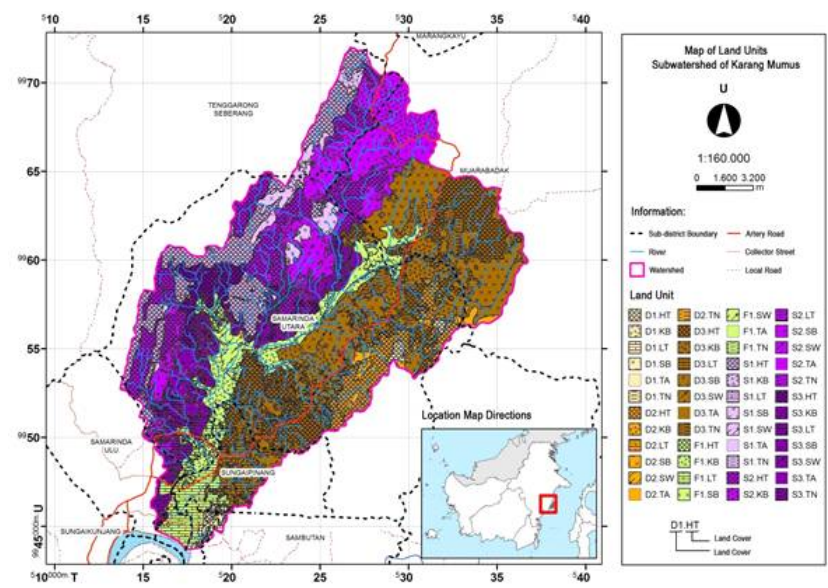

Figure 3 Map of land system distribution in Karang Mumus Sub-Watershed.

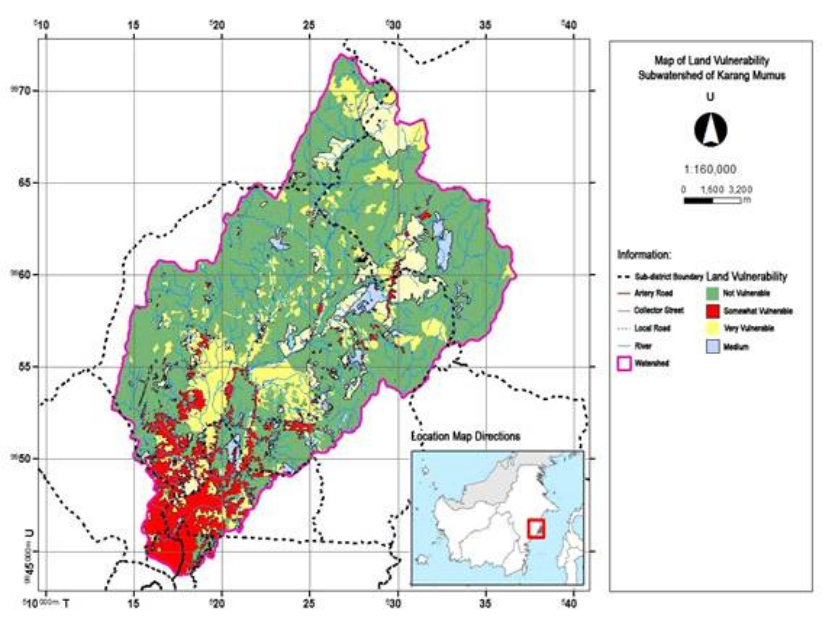

Figure 5 Map of land vulnerability in Karang Mumus SubWatershed.

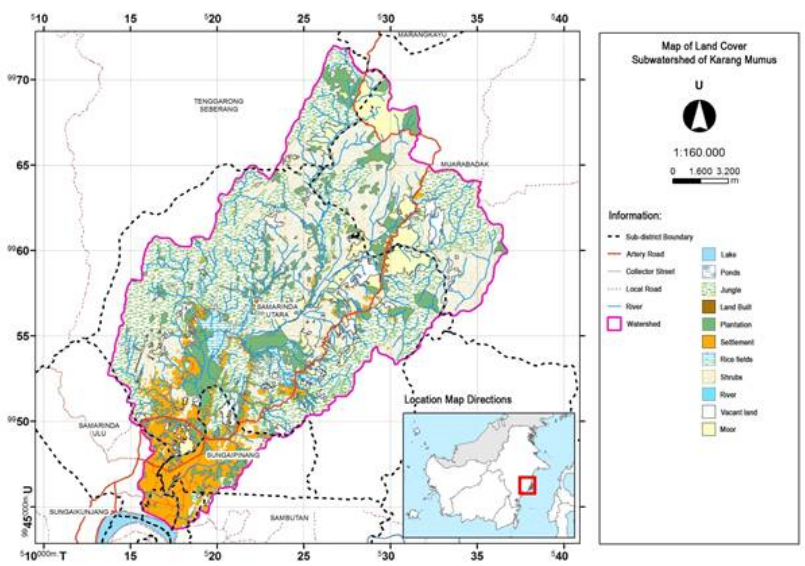

Figure 4 Map of land cover in Karang Mumus SubWatershed.

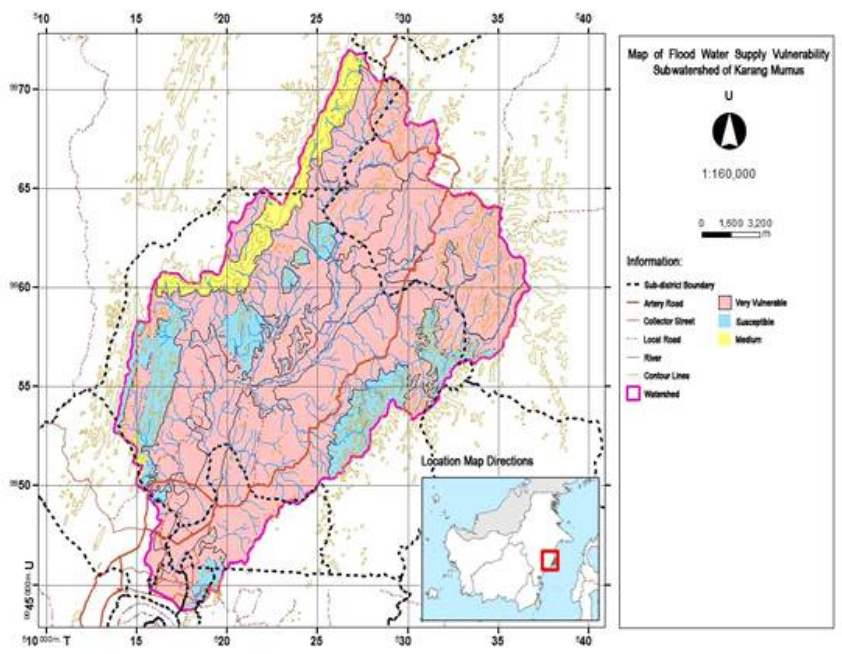

Figure 6 Map of flood water supply vulnerability in Karang Mumus Sub-Watershed 
Mumus Sub-Watershed are scattered in Karang Mumus Hilir and Siring Sub-Watersheds. These areas have a slope of $<2 \%$ and are located around the main river, and tributaries of Pampang River, Karang Mumus Hulu River, and Lantung River. A map depicting flood prone areas can be seen in Figure 7.

Karang Mumus Sub-Watersheds' flood prone area that belongs to Samarinda Utara Sub-District is Karang Mumus Hilir Sub-Sub-Watershed which puddle can potentially reach $76 \%$ of the total area of the Sub-Watershed. Meanwhile, the flood-prone areas in Sungai Pinang Sub-District are Siring, Jaya Mulya, and Betapus Sub-Watersheds with potential puddle occurrences of $39 \%, 21 \%$ and $33 \%$, respectively. These areas are susceptible to flooding because they have a slope of less than $2 \%$. Furthermore, these areas are affected by the ebb and flow of the ocean and the confluence of larger rivers. In terms of water catchment area (daerah tangkapan air, DTA), Karang Mumus Sub-Watershed is categorized as vulnerable or high.

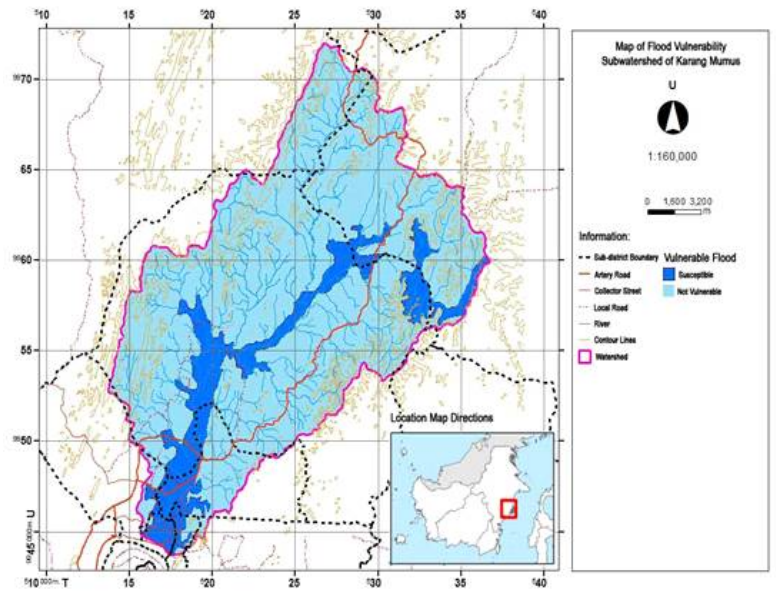

Figure 7 Map of flood prone areas in Karang Mumus SubWatershed.

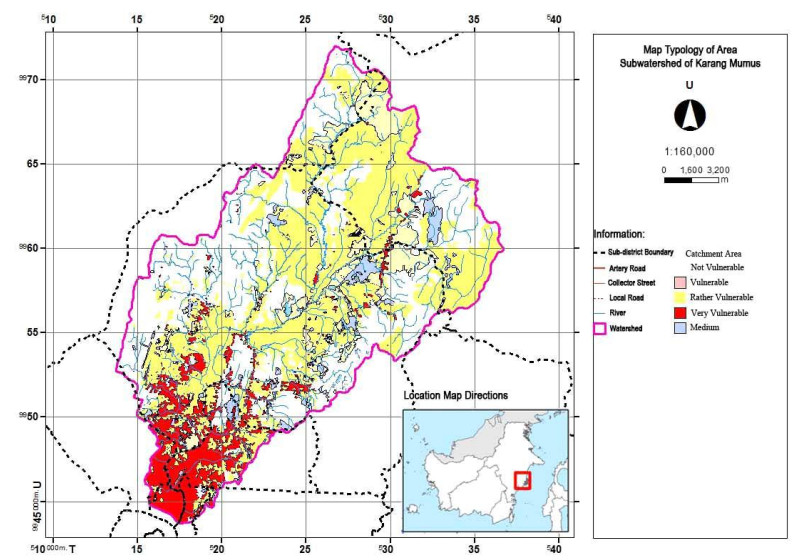

Figure 8 Map of water catchment area typology in Karang Mumus Sub-Watershed.
The Interconnection between the socio-economic and biophysical aspects of the sub-watershed performance Considering the vulnerability of each aspect, where socioeconomic typologies included in the vulnerable category and land typology are categorized as vulnerable category, the water catchment area (DTA) of Karang Mumus SubWatershed is categorized as vulnerable or high. The same applies to Sub-Watershed management typology, which serves as a manifestation of the DTA typology. Since the territorial typology of sub-watershed management typology is categorized as medium and DTA typology is categorized as high, the sub-watershed management typology us categorized as high or vulnerable. The DTA typology and Karang Mumus Sub-Watershed management typology can be seen in Figure 8 and Figure 9, respectively. Both DTA and Karang Mumus Sub-Watershed management typologies are categorized as vulnerable (approximately 64\% of Karang Mumus Sub-Sub-Watershed). This vulnerability is due to the fact that Karang Mumus Sub-Watershed belongs to many sub-districts and thus creating a much more complex problem. This problem must not only be solved by institutions directly related to the cause but also by all agencies in the districts belonging to the Karang Mumus Sub-Watershed. To do that, a well-coordinated joint management of relevant districts that is led by the mayor must be established.

Karang Mumus is a priority sub-watershed that requires better management so as to restore environmental quality. Karang Mumus Hulu Sub-Sub-Watershed (Samarinda Utara and Sungai Pinang Sub-Districts) becomes a priority since its socio-economic and biophysical vulnerabilities range from vulnerable to very vulnerable. To solve these problems, especially the one occurring in the upstream region of Karang Mumus Sub-Watershed, measures to improve the environmental quality such as water conservation, both through vegetative measures and civil engineering, as well as economic improvements must be performed expeditiously. Socio-economic vulnerability is closely related to biophysical vulnerability. In two sub-districts in the

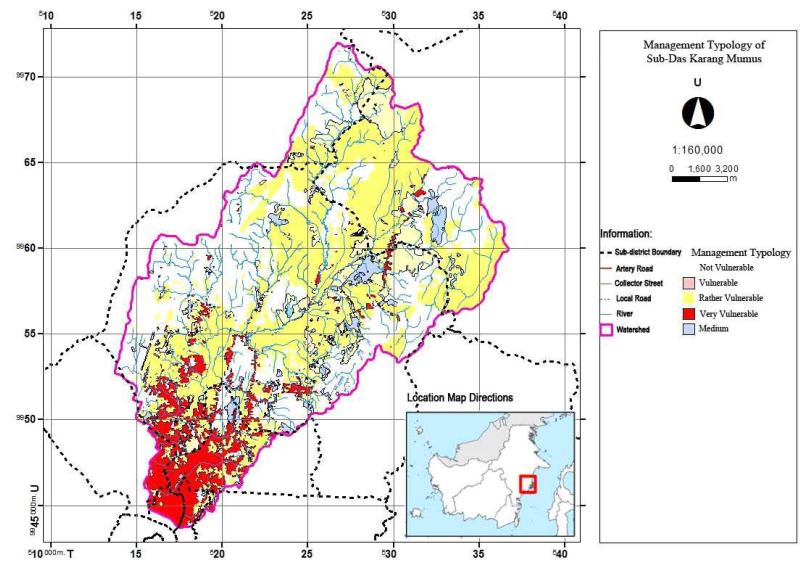

Figure 9 Map of sub-watershed management typology of Karang Mumus Sub-Watershed. 
upstream region of Karang Mumus Sub-Watershed, namely Samarinda Utara and Sungai Pinang, the per capita income of the population still depends on a vegetable-dominated agriculture. The upstream region of Karang Mumus SubWatershed is a flood supplying area with high rainfall. Meanwhile, the downstream region (Samarinda Kota SubDistrict) is a flood-prone area with dominant income from the manufacturing sector. Karang Mumus Sub-Watershed is similar to Pampang and Siring Sub-Watersheds since their upstream region is a flood water supplying area with high rainfall agriculture-based economic structure, while the downstream region is a flood-prone area dominated by the service sector(Sanudin, 2007).

The differences between the socio-economic and biophysical aspects of both the upstream and downstream regions require appropriate solutions. Each resolution must be performed on a case by case basis. Such differences are identified after sub-watershed performance is monitored and evaluated. The results reveal that the upstream region has a high rainfall, high land vulnerability, and an agriculturebased economic structure. Thus, the inhabitants must be urged to gain income from another sector that can minimize the damages inflicted to the land. High rainfall is the source of the flood water supply. Therefore, rehabilitative measures in the form of both vegetative measures and civil engineering must be performed in the downstream region. Some of these solutions will not yield instant results and require a lengthy process. Therefore, the monitoring and evaluation need to be carried out periodically (Becerra, 1995) so that the subwatersheds' periodic health can be observed. To overcome this problem, the Office of Public Works has created a master plan. However the implementation is still constrained by the lack of funding and difficult land acquisition.

Collaborative management Sub-watershed management is inseparable from the biophysical and socio-economic conditions that vary between the upstream and downstream regions. The upstream region of Karang Mumus SubWatershed where Samarinda Utara and Sungai Pinang SubDistricts are located is dominated by vegetable patches causing land degradation and high level erosion and as well as considerable sedimentation, especially in Benanga Hydropower Center, which many fear would cause an energy crisis in the surrounding area. In addition, high population density has resulted in high economic vulnerability. In the central and downstream regions, Karang Mumus SubWatershed is prone to streambank erosion due to illegal sand mining.

Furthermore, the central and downstream regions are flood-prone areas due to being dominated by plains and having a slope of less than $2 \%$. Aside from that, these areas are also affected by ebb and flow of the ocean as well the confluence of larger rivers. Therefore, solutions are needed to determine the approach for sub-watershed management. One of these solutions is called the collaborative management. Collaborative management is a conflict resolution that accommodates cooperation (Wiyono, 2008). The most important element of the collaborative management is a "participation" involving all "stakeholders". Karang Mumus Sub-Watershed flows through many sub-districts and thus requires the role of mayor capable of coordinating all stakeholders. Every stakeholder surely has his or her own interests and view. Therefore, the role of a mayor capable of synergizing the various interests of the stakeholders is needed. Considering the urgency of sub-watershed management issues and the adverse impacts they have, solutions must be formulated and implemented as soon as possible. Such solutions include rehabilitative measures such as land conservation, both through vegetative measures and civil engineering, reforestation, and agricultural improvements for crops such as rice.

Conservation can be performed by planting trees, such as mahogany, golden teak, etc., on the vulnerable land (along the sub-watershed). In the fisheries sector, conservation can be performed by breeding catfish, mujair (mozambique tilapia), nila (nile tilapia), etc. In the livestock sector, conservation can be performed by raising goats, buffaloes and cows. The abovementioned activities can be performed in the upstream region (Samarinda Utara and Sungai Pinang Sub-Districts) to enable the locals to improve their economy. As for the downstream region, such Samarinda Kota Samarinda Ilir Sub-Districts that relies on the processing of raw materials for the purpose of manufacturing industry, industries for chips (potato, banana, and breadfruit), corned meat (beef and goat), cracker (buffalo skin and fish), etc. These activities cannot be done without the intervention of relevant agencies, NGOs as well as academics serving as the facilitators. Successful collaborative management will surely have enormous positive implications on the society in general. Biophysically, water availability will be more reliable and thus capable of supporting the food industry since water is available throughout the year. In turn, public welfare will also be improved due to the growing food business. The economic activities in general will not be disrupted since the number of flood and landslide will begin to dwindle. The success of collaborative sub-watershed management will serve as reference data that can encourage policyholders to manage the sub-watershed using the method.

\section{Conclusion}

The socio-economic and biophysical aspects of Karang Mumus Sub-Watershed are considered very vulnerable. This is due to the lack of sub-watershed management performed hitherto. In performing the management, the Municipal Administration of Samarinda must work closely with NGOs, academics, stakeholders, and the community to achieve better effectiveness and efficiency. Thus, the "collaborative management" needs to be synergized and improved further.

\section{Acknowledgements}

This research was supported by the Ph.D grant of the Indonesia Endowment Fund for Education (LPDP-BUDI DN 2016) of the Ministry of Finance of the Republic of Indonesia (No. PRJ-4803/LPDP.3/2016).

\section{References}

Amin, A. (2009). Pernyataan keprihatinan terhadap fenomena banjir, Kalimantan Timur. Retrieved from 
http://www.mail-archive.com/envorum@ypb/or.id/ msg01949 html

Bawole, R., Rumere, R., Mudjirahayu, \& Pattiasina, T. P. (2013). Performance of coral reef management: Integrating ecological, socio economic, technological, and institutional dimensions. Jurnal Manajemen Hutan Tropika, 19(1), 63-73. https://doi.org/10.7226/ jtfm.19.1.63

Becerra, E. H. (1995). Monitoring and evaluation of watershed management project achievements. FAO Conservation Guide 24.

BPS [Central Bureau of Statistics]. (2017). Samarinda dalam angka tahun 2017. Samarinda: BPS Samarinda.

Burgess, R., Hansen, M., Olken, B., \& Sieber, S. (2010). The political economy of deforestation in the tropics. Coventry: The University of Warwick.

Innah, H. S., Suharjito, D., Dharmawan, A. H., \& Darusman, D. (2013). Collective action typologies and reforestation in indigenous community of Biak-Papua. Jurnal Manajemen Hutan Tropika, 19(1), 11-22. https:// doi.org/10.7226/jtfm.19.1.11

Karminarsih, E. (2007). The use of ecosystemmangrove in minimalize disaster impact in beach area. Jurnal Manajemen Hutan Tropika, 18(3), 182-187.

Kartodihardjo, H., Didik, S., Bramasto, N., \& Ahmad, D. (2013). Development of small holder plantation forests: An analysis from policy process perspective. Jurnal Manajemen Hutan Tropika, 19(2), 111-118. https://doi.org/10.7226/jtfm.19.2.111

Mulyanto, L., \& Jaya, I. N. S. (2004). Spatial analysis on forest degradation and deforestation: Acase study in Duta Maju Timber, West Sumatera. Jurnal Manajemen Hutan Tropika, 10(1), 29-42.

Nugroho, B. (2011). Land right community forest plantation policy: Analysis from institutional perspectives. Jurnal Manajemen Hutan Tropika, 17(3), 111-118.

Paimin, Sukresno, Tyas, M., Basuki, \& Purwanto. (2002). Monitoring dan evaluasi daerah aliran sungai dalam perspektif diagnosa kesehatannya. Paper presented at Seminar Monitoring dan Evaluasi Pengelolaan DAS. Surakarta, Indonesia.

Paimin. (2009). Laporan akhir hasil penelitian tahun 20032009. Usulan kegiatan hasil penelitian (UKP). Sistem karakterisasi daerah aliran sungai. Solo: Balai Penelitian Kehutanan Solo.

Purwanto, J., Rusolono, T., \& Prasetyo, L. B. (2015). Spatial model of deforestation in Kalimantan from 2000 to 2013. Jurnal Manajemen Hutan Tropika, 21(3), 110-118. https://doi.org/10.7226/jtfm.21.3.110
Rusdiana, O., Sudaryanto, Ichwandi, I., Arifjaya, N. M., Hendrayanto, \& Soekmadi, R. (2013). Hubungan kerjasama institusi dalam pengelolaan daerah aliran sungai kasus DAS Ciliwung. Bogor: Fakultas Kehutanan Institut Pertanian Bogor

Sanudin, \& Antoko, B. S. (2007). Kajian sosial ekonomi masyarakat di DAS Asahan, Sumatra Utara. Jurnal Penelitian Sosial dan Ekonomi Kehutanan, 4(4), 355-367.

Sembiring, S., Basuni, S., \& Soekmadi, R. (2010). Conflict resolution of Teluk Cenderawasih National Park management in Teluk Wondama Regency. Jurnal Manajemen Hutan Tropika, 16(2), 84-91.

Siahaan, C. H. (2008). Semua bupati punya saham? Retrieved from https://www.bongkar.co.id/news/ pertambangan/505-semua-bupati-punya-saham.html

Soedomo, S. (2013). Total economic value in investment analysis. Jurnal Manajemen Hutan Tropika, 19(2), 201-207. https://doi.org/10.7226/jtfm.19.3.201

Suarga, R. (2005). Pemberantasan illegal logging optimisme di tengah praktek premanisme global. Jakarta: Wana Aksara.

Sulistiyono, N., Jaya, I. N. S., Prasetyo, L. B., \& Tiryana, T. (2015). Spatial model of deforestation in Sumatera Island using typological approach. Jurnal Manajemen Hutan Tropika, 21(3), 99-109. https://doi.org/10.7226/ jtfm.21.3.99

Susilo, H. (2009). 35 DAS di Jawa Tengah kritis. Kompas, 7 April 2009.

Timpakul. (2007). Hutan Kaltim menuju fase kegelapan. Retrieved from http://timpakul.hijaubiru.org/hutan12.html

Turner, B. L. II, Skole, D., Sanderson, S., Fischer, G., Fresco, L., \& Leemans, R. (1995). Land-use and land-cover change; Science/Research Plan. IGBP Report No. 35, HDP Report No. 7. IGBP and HDP, Stockholm and Geneva

Walker, J., Alexander, D., Irons, C., Jones, B., Penridge, H., \& Rapport, D. (2006). Catchment health indicators: An overview. In J. Walker, \& D. J. Reuter, Indicators of cacthment health. A technical perspective. Australia: CSIRO.

Wijaya, P. A., Saleh, M. B., \& Tiryana, T. (2015). Spatial model of deforestation in Jambi Province for the periode 1990-2011. Jurnal Manajemen Hutan Tropika, 21(3), 128-137. https://doi.org/10.7226/jtfm.21.3.128

Wiyono, T. P. (2008). Pentingnya partisipasi dan penguatan kelembagaan masyarakat dalam pengelolaan hutan Jawa. Paper preesnted at Kursus Pengelolaan Hutan. DERAS 
Training Centre. Yogyakarta, Indonesia.

www.KaltimPOS.com. 2019. Banjir Samarinda 2019 ini mirip banjir 1998. Retrieved from http://kaltim.prokal. co/read/news/356739-banjir-samarinda-2019-ini-miripbanjir-1998.html.
Zulkarnaen, I. (2008). Catatan akhir tahun - Banjir berkalikali, catatan kelam Samarinda 2008. Retrieved from http://www.news.id.finroll.com/catatan-akhirtahun/3578-catatan-akhir-tahun-banjir-berkali-kalicatatan-kelam-samarinda-2008-olehiskandarzulkarnaen.html 